\title{
Analisis Current Ratio, Debt to Equity, Firm Size dan Working Capital terhadap Return on Equity pada Perusahaan Transportasi
}

\author{
Jony \\ Universitas Pelita Harapan, Medan Indonesia \\ Jony.mdn@lecturer.uph.edu
}

Corresponding Author : Jony

Submitted: 22 Mei 2020

Accepted: 26 Juni 2020

Published: 1 Agustus 2020

\begin{abstract}
ABSTRAK
Penelitian ini bertujuan untuk membuktikan dan menganalisis pengaruh current ratio, debt to equity ratio, firm size dan working capital terhadap return on equity. Pada perusahaan transportasi yang terdaftar di Bursa Efek Indonesia tahun 2015 - 2018. Populasi dalam penelitian ini adalah 33 perusahaan transportasi yang terdaftar di Bursa Efek Indonesia tahun 2015-2018. Berdasarkan` 33 perusahaan yang terdaftar, terpilih 10 sebagai perusahaan sampel dengan menggunakan purposive sampling. Hasil pembahasan menunjukkan bahwa secara simultan pada hasil pengujian yang dilakukan secara simultan current ratio, debt to equity ratio, firm size dan working capital berpengaruh terhadap return on equity. Pada perusahaan transportasi yang terdaftar di Bursa Efek Indonesia tahun 2015-2018. Berdasarkan hasil penelitian yang dilakukan secara parsial tidak terjadinya pengaruh antara current ratio terhadap current ratio, debt to equity ratio, firm size dan working capital terhadap return on equity pada perusahaan transportasi yang terdaftar di Bursa Efek Indonesia tahun 2015-2018 dan Sementara nilai koefisien determinasi disesuaikan ( $\mathrm{R}$ square) sebesar $63.1 \%$. Hal ini memiliki arti bahwa $36.9 \%$ pengaruh return on asset dapat dijelaskan oleh variasi dari ketiga variabel independen yaitu current ratio, debt to equity ratio, firm size dan working capital Sedangkan sisanya sebesar 48, 6\% dijelaskan oleh variabel lain yang tidak diteliti pada penelitian ini.
\end{abstract}

Keywords : current ratio, debt to equity ratio, working capital, firm size dan return on equity.

\section{PENDAHULUAN}

Perusahaan sektor transportasi adalah bagian yang sangat penting bagi seluruh aktivitas kegiatan ekonomi, terutama untuk perekonomian yang terkait dengan penjualan barang. Transportasi dibutuhkan untuk mengirimkan barang yang dibeli oleh satu perusahaan, kemudian distribusi antar bagian unit perusahaan yang berbeda lokasi, dan juga terhadap penjualan produk perusahaan. Kemampuan melakukan distribusi dengan lancar sangat berpengaruh terhadap daya saing perusahaan. Pelaksanaan distribusi dapat dilakukan secara internal oleh perusahaan dan dapat diserahkan kepada pihak eksternal perusahaan sehingga dapat mengarahkan fokus perusahaan ke kegiatan inti perusahaan. Perusahaan yang menerima pekerjaan untuk melakukan 
distribusi ini disebut dengan perusahaan sektor transportasi, tidak terbatas pada transportasi barang, tetapi juga sumber daya manusia.

Kinerja keuangan perusahaan merupakan hasil atau prestasi yang dicapai manajemen dalam mengelola aset perusahaan secara efektif (Rudianto, 2013). Untuk dapat mengukur kinerja keuangan dapat menggunakan rasio profitabilitas dimana salah satu yang dipakai dalam penelitian ini adalah return on equity. Hal ini dikarenakan bahwa kinerja keuangan adalah untuk melihat keuntungan (profit) perusahaan.

Likuiditas merupakan kemampuan suatu perusahan untuk dapat memenuhi kewajibannya membayar utang-utang jangka pendeknya seperti utang usaha, utang dividen, utang pajak, dan lainnya (Rudianto, 2013). Perusahaan dianggap memiliki kinerja yang baik jika memiliki tingkat likuiditas yang tinggi, dibandingkan dengan perusahaan yang memiliki likuiditas yang rendah.

Debt to Equity Ratio atau dalam bahasa Indonesia disebut dengan rasio hutang terhadap ekuitas, atau rasio hutang modal; merupakan suatu rasio keuangan yang menunjukkan proporsi relatif antara ekuitas dan hutang yang digunakan untuk membiayai aset perusahaan. Perusahaan yang memiliki debt to equity ratio atau rasio hutang terhadap ekuitas yang tinggi mungkin tidak dapat menarik tambahan modal dengan pinjaman dari pihak lain.

Ukuran perusahaan merupakan faktor penting dalam menentukan kinerja keuangan perusahaan. Perusahaan yang memiliki ukuran perusahaan yang lebih besar mempunyai pengaruh terhadap profitabilitas perusahaan. Modal kerja merupakan jumlah aktiva lancar yang dimiliki oleh perusahaan untuk membiayai kegiatan sehari hari.

Beberapa penelitian yang pernah dilakukan sebelumnya dengan variabel profitabilitas antara lain yang menyatakan bahwa current ratio tidak berpengaruh signifikan terhadap return on equity karena berdasarkan hasil tersebut manajer perusahaan perlu menjaga tingkat likuiditas perusahaan karena apabila tingkat likuiditas baik, maka perusahaan dalam menghasilkan laba perusahaan juga akan meningkat (Zaman et al., 2017). Makhdalena yang menyatakan bahwa firm size berpengaruh terhadap kinerja keuangan perusahaan karena perusahaan besar memiliki assets yang besar (Makhdalena, 2018). Dengan memiliki assets yang besar, perusahaan akan memperoleh penghasilan yang besar pula. Isbanah menyatakan bahwa perusahaan akan menjadi kurang baik apabila menggunakan utang semakin besar (Isbanah, 2015). Dengan sumber dana yang lebih besar, keuntungan dapat meningkat namun diikuti pula dengan peningkatan resiko yang lebih besar dari peningkatan keuntungan sehingga hasil penelitian ini juga menunjukkan bahwa leverage tidak berpengaruh terhadap return on equity. Di dalam penelitian ini, peneliti akan menguji dan menganalisa faktor yang mempengaruhi return on equity pada perusahaan transportasi yang terdaftar di Bursa Efek Indonesia pada periode $2015-2018$.

Berdasarkan latar belakang masalah di atas maka dapat dilakukan perumusan masalahnya yaitu apakah variabel current ratio, debt to equity ratio, working capital dan firm size secara parsial dan secara simultan akan berpengaruh terhadap return on equity pada perusahaan transportasi yang terdaftar di Bursa Efek Indonesia pada periode 2015 - 2018. Sementara tujuan penelitian ini untuk menganalisa pengaruh masing - masing variabel yang diteliti seperti variabel current ratio, debt to equity ratio, working capital dan firm size terhadap return on equity.

\section{TINJAUAN PUSTAKA \\ 2.1. Current Ratio}

Hantono menjelaskan bahwa current ratio merupakan rasio yang menunjukkan jumlah kewajiban lancar yang dijamin 
pembayarannya oleh aktiva lancar sehingga semakin tinggi hasil perbandingan aktiva lancar dengan kewajiban lancar maka semakin tinggi pula kemampuan perusahaan untuk dapat menutupi kewajiban jangka pendeknya (Hantono, 2018).

$$
\text { Current Ratio }=\frac{\text { Current Asset }}{\text { Current Liabilities }}
$$

\subsection{Debt to Equity Ratio}

Hantono menyatakan bahwa debt to equity (DER) merupakan rasio yang menunjukkan sejauh mana modal sendiri menjamin seluruh utang (Hantono, 2018). Menurut Sartono, cara untuk menghitung debt to equity ratio (Sartono, 2012) adalah perbandingan total hutang dibandingkan dengan total modal sendiri, atau dirumuskan dengan:

Debt to Equity Ratio

\subsection{Firm Size}

$$
=\frac{\text { Total Hutang }}{\text { Total Modal Sendiri }}
$$

c umum proksi size dipakai logaritma (log) atau logaritma natural asset.

$$
\text { Size }=\operatorname{Ln}(\text { Total Asset })
$$

\subsection{Working Capital}

Menurut Kasmir, modal kerja merupakan investasi yang dapat ditanamkan dalam aktiva lancar atau aktiva jangka pendek seperti kas, bank, surat berharga, piutang, persediaan dan aktiva lancar (Kasmir, 2013).

\subsection{Return on Equity}

Menurut Hantono, return on equity merupakan rasio yang menunjukkan tingkat pengembalian yang diperoleh pemilik bisnis dari modal yang telah dikeluarkan untuk bisnis tersebut, yang dihitung dengan perbandingan antara keuntungan bersih perusahaan setelah pajak dan bunga terhadap nilai ekuitas perusahaan (Hantono, 2018). Jika dirumuskan akan terlihat sebagai berikut:

$$
R O E=\frac{\text { Earning After Interest \& Tax }}{\text { Equity }}
$$

\subsection{Pengaruh Current Ratio Terhadap Return on Equity}

Menurut Hantono, menyatakan bahwa current ratio berpengaruh signifikan terhadap return on equity (Hantono, 2015). Menurut Sunyoto, apabila tingkat rasio tinggi menunjukkan jaminan lebih baik atas hutang jangka pendek, tetapi apabila terlalu tinggi berakibat pada modal kerja yang tidak efisien (Sunyoto, 2013). Semakin tinggi current ratio suatu perusahaan berarti semakin kecil resiko kegagalan perusahaan dalam memenuhi kewajiban jangka pendeknya. Akibatnya resiko yang akan ditanggung pemegang saham juga semakin kecil. Alpi menjelaskan bahwa perusahaan tidak memilki kemampuan dan kesempatan untuk memenuhi kewajiban jangka pendeknya dan sebaliknya apabila rasio lancar dalam perusahaan mengalami peningkatan maka dapat dikatakan baik bagi perusahaan tersebut (Alpi, 2018). Hal ini disebabkan karena perusahaan memiliki kemampuan untuk dapat memenuhi kewajiban jangka pendeknya kepada pihak kreditur sehingga menunjukkan bahwa current ratio berpengaruh signifikan terhadap return on equity. Berdasarkan uraian diatas, peneliti dapat mengajukan hipotesis dasar berikut:

\section{$\mathrm{H}_{1}$ : Current Ratio Berpengaruh Signifikan Terhadap Return on Equity}

\subsection{Pengaruh Debt to Equity Ratio Terhadap Return on Equity}

Menurut Hantono menyatakan bahwa debt to equity ratio berpengaruh signifikan terhadap return on equity (Hantono, 2015). Pada saat debt to equity ratio meningkat maka return on equity akan meningkat, begitu juga sebaliknya apabila nilai debt to equity ratio menurun maka return on equity juga akan menurun. Artinya, perusahaan memiliki hutang yang besar dan juga memiliki modal yang besar (Violita \& Sulasmiyati, 2017). Menurut Jannati menjelaskan bahwa debt to equity ratio menunjukkan hubungan 
antara jumlah pinjaman jangka panjang yang diberikan oleh kreditur dengan jumlah modal sendiri yang diberikan oleh pemilik perusahaan sehingga semakin tinggi rasio ini akan mempengaruhi tingkat pendapatan bersih yang tersedia bagi pemegang saham (Jannati, 2014). Menurut Mareta yang menyatakan bahwa perusahaan harus benar-benar memperhatikan rasio debt to equity ratio sebelum melakukan hutang (Mareta, 2013). Dalam penelitian ini dijelaskan bahwa debt to equity ratio berpengaruh positif dan signifikan terhadap return on equity. Berdasarkan uraian diatas, peneliti dapat mengajukan hipotesis dasar berikut: $\mathrm{H}_{2}$ : Debt to Equity Ratio Berpengaruh Signifikan Terhadap Return on Equity

\subsection{Pengaruh Firm Size Terhadap Return on Equity}

Menurut Wibowo menjelaskan bahwa perusahaan besar yang dianggap telah mencapai tahap kedewasaan merupakan suatu gambaran bahwa perusahaan tersebut relatif lebih stabil dan lebih mampu menghasilkan laba dibandingkan perusahaan kecil sehingga semakin besar aktiva maka akan semakin banyak modal yang ditanam, banyak perputaran uang dan besar kapitalisasi pasar maka akan meningkatkan kinerja keuangan perusahaan (Wibowo, 2019). Menurut Isbanah menjelaskan bahwa semakin besar ukuran perusahaan maka semakin rendah kinerja keuangannya (Isbanah, 2015). Hal ini dapat disebabkan ukuran perusahaan yang besar tersebut belum didukung pengelolaan yang bagus sehingga ukuran perusahaan tidak bisa digunakan sebagai jaminan bahwa perusahaan yang besar memiliki kinerja yang bagus. Talebnia menjelaskan bahwa tidak terdapat pengaruh ukuran perusahaan terhadap kinerja perusahaan (Talebnia et al., 2010). Hal ini menunjukkan bahwa ukuran perusahaan bukan jaminan bahwa perusahaan akan memiliki kinerja yang baik. Berdasarkan uraian diatas, peneliti dapat mengajukan hipotesis dasar berikut:

$\mathrm{H}_{3}$ : Firm Size Berpengaruh Signifikan Terhadap Return on Equity

\subsection{Pengaruh Working Capital} Terhadap Return on Equity

Menurut Bulan menjelaskan bahwa modal kerja yang cukup lebih baik daripada modal kerja yang berlebihan (Bulan, 2015). Modal kerja yang berlebihan menunjukkan bahwa perusahaan tidak mampu menggunakan modal kerja yang ada dengan baik, sehingga dana tersebut menjadi tidak produktif. Hal ini akan berakibat terhadap likuiditas dan tingkat pengembalian modal kerja perusahaan. Sebaliknya modal kerja yang tidak cukup akan dapat menyebabkan kegagalan suatu perusahaan dalam mengelola likuiditas dan menurunkan tingkat profitabilitas. Menurut Tnius menjelaskan bahwa penurunan modal kerja ini disebabkan oleh unsur-unsur aktiva lancar yang dikelola seperti kas, piutang, dan persediaan yang menyebabkan perubahan mengalokasikan dana untuk aktivitas lainnya (Tnius, 2018). Menurut Wardojo menjelaskan bahwa modal kerja perlu dikelola dengan benar oleh manajemen perusahaan agar memberikan keuntungan yang maksimal kepada pemilik perusahaan (Wardojo et al., 2004). Berdasarkan uraian diatas, peneliti dapat mengajukan hipotesis dasar berikut:

$\mathrm{H}_{4}$ : Working Capital Berpengaruh Signifikan Terhadap Return on Equity

\section{Metode Penelitian}

\subsection{Jenis Penelitian}

Penelitian ini menggunakan metode pendekatan kuantitatif. Sugiyono mengungkapkan bahwa penelitian kuantitatif yaitu metode penelitian yang menggunakan analisis statistik (Sugiyono, 2015). Jenis penelitian yang dipakai adalah statistik deskriptif yang memberikan gambaran berupa data statistik secara sistematis sehingga tidak membentuk kesimpulan yang bersifat umum. Pengumpulan data dalam 
penelitian ini menggunakan metode studi dokumentasi. Data yang digunakan dalam penelitian ini berasal dari laporan keuangan perusahaan transportasi yang terdaftar di Bursa Efek Indonesia periode tahun 2015 - 2018 .

\subsection{Populasi dan Sampel}

Populasi yang terdapat dalam penelitian ini sebanyak 33 perusahaan transportasi yang terdaftar di Bursa Efek Indonesia tahun 2015 - 2018. Pemilihan sektor transportasi adalah salah satunya sebagai pembeda dari penelitian sebelumnya dan menjadi karakter penelitian ini. Cara pengambilan sampel adalah dengan menggunakan metode purposive sampling. Sugiyono mengungkapkan bahwa purposive sampling merupakan salah satu teknik dalam mengambil sampel dengan beberapa pertimbangan tertentu (Sugiyono, 2015). Beberapa kriteria yang digunakan untuk menentukan sampel dalam penelitian ini, yaitu

Tabel 1. Kriteria Pengambilan Sampel

\begin{tabular}{|c|c|}
\hline $\begin{array}{lcc}\text { Perusahaan } & \text { Sub } & \text { Sektor } \\
\text { Transportasi } & \text { yang terdaftar di } \\
\text { Bursa Efek } & \text { Indonesia } & \text { tahun } \\
2015-2018 & & \\
\end{array}$ & 33 \\
\hline $\begin{array}{lrr}\text { Perusahaan } & \text { Sub } & \text { Sektor } \\
\text { Transportasi yang } & \text { tidak } \\
\text { mempublikasikan } & \text { laporan } \\
\text { keuangan secara lengkap tahun } \\
2015 \text { - 2018. }\end{array}$ & (9) \\
\hline $\begin{array}{lcr}\text { Perusahaan } & \text { Sub } & \text { Sektor } \\
\text { Transportasi } & \text { yang } & \text { tidak } \\
\text { menggunakan } & \text { mata uang rupiah }\end{array}$ & (14) \\
\hline $\begin{array}{c}\text { Jumlah perusahaan yang } \\
\text { terpilih menjadi sampel } \\
\text { penelitian }\end{array}$ & 10 \\
\hline
\end{tabular}

\section{Hasil dan Pembahasan \\ 4.1 Statistik Deskriptif}

Uji statistik deskriptif dilakukan untuk mengetahui deskripsi data penelitian yang ditunjukkan dari hasil rata-rata (mean) sebagai besarnya rata rata populasi yang diperkirakan dari sampel, maksimum minimum nilai dalam populasi dan standar deviasi (standard deviation) dalam menilai rata-rata dispersi dari sampel yang digunakan. Hasil analisis statistik deskriptif dapat dilihat di bawah ini sebagai berikut:

Tabel 2. Statistik Deskriptif

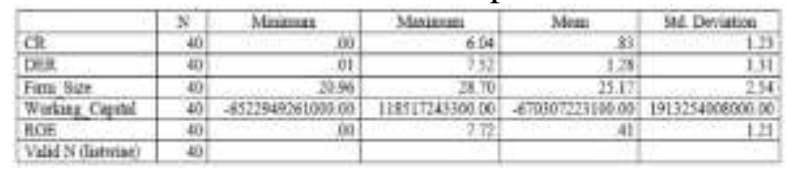

Sumber: Hasil Pengolahan, 2020

\subsection{Uji Asumsi Klasik}

\subsubsection{Uji Normalitas}

Hasil pengujian data menunjukkan bahwa data dalam penelitian ini tidak mengalami masalah pada pengujian asumsi klasik, dimana uji multikolinearitas, uji heteroskedastisitas dan uji autokorelasi memenuhi syarat. Hasil pengujian normalitas data menggunakan analisis grafik dapat dilihat dari gambar 1 di bawah ini:

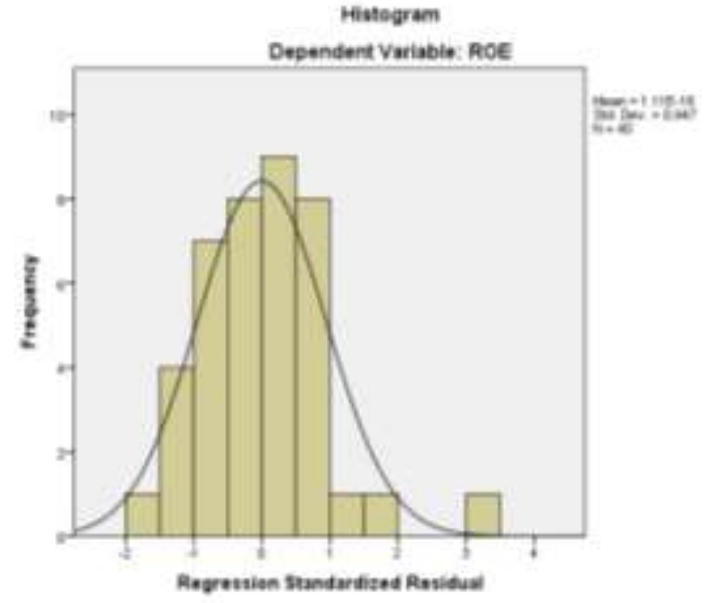

Gambar 1. Histogram Normalitas Data

Sumber: Hasil Pengolahan, 2020

Pada gambar $1 \mathrm{di}$ atas menunjukkan garis kurva cenderung simetri (U) maka dapat dikatakan data berdistribusi normal. Hasil normal probability plot dalam penelitian ini dapat dilihat pada gambar 2 berikut: 


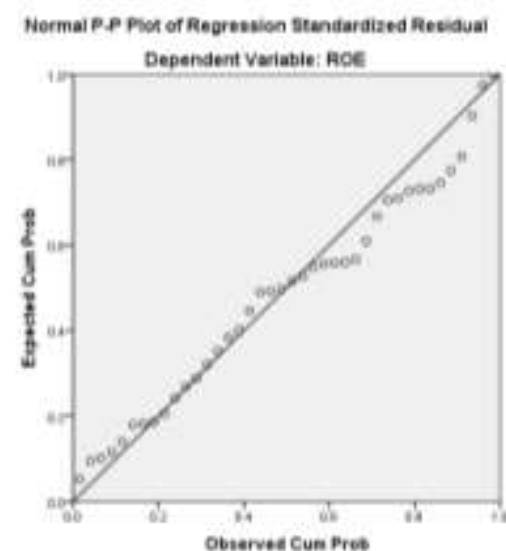

Gambar 2. Normal Probability Plots

Sumber : Hasil Pengolahan, 2020

Pada gambar 2 terlihat grafik normal probability plots memiliki titik yang menyebar di sekitar garis normal dan mengikuti arah garis diagonal sehingga menunjukkan bahwa data terdistribusi secara normal, maka model regresi memenuhi asumsi normalitas. Hasil uji Kolmogorov Smirnov dapat dilihat pada tabel 2 sebagai berikut :

Tabel 3. Pengujian Normalitas dengan Kolmogorov-Smirnov

\begin{tabular}{cccc}
\hline $\mathrm{N}$ & $\begin{array}{c}\text { Kolmogorov } \\
- \text { Smirnov }\end{array}$ & $\begin{array}{c}\text { Asymp. } \\
\text { Sig. (2- } \\
\text { tailed) }\end{array}$ & Ket \\
\hline 40 & .117 & 176 & Normal \\
\hline
\end{tabular}

\section{Sumber : Hasil Pengolahan, 2020}

Hasil uji normalitas Kolmogorov Smirnov pada tabel 2. menunjukkan bahwa nilai signifikan $0,117>0,05$ dengan demikian hasil uji normalitas Kolmogorov Smirnov dapat diambil kesimpulan data berdistribusi normal.

\subsubsection{Uji Multikolinearitas}

Uji multikolinieritas dilakukan dengan membandingkan nilai tolerance dan VIF. Jika nilai Tolerance diatas 0,1 dan VIF dibawah 10 maka bisa dikatakan tidak terjadi multikolinieritas.

Hasil pengujian multikolinearitas dalam penelitian ini adalah sebagai berikut:
Tabel 4. Pengujian Multikolinearitas

\begin{tabular}{ccc}
\hline Variabel & Tolerance & VIF \\
\hline CR & .930 & 1.075 \\
DER & .848 & 1.180 \\
Firm_Size & .719 & 1.390 \\
Working_Capital & .816 & 1.226 \\
\hline
\end{tabular}

\section{Sumber : Hasil Pengolahan, 2020}

Berdasarkan tabel 3. di atas menunjukkan nilai tolerance untuk variabel current ratio, debt to equity ratio, firm size dan working capital berada di atas 0,10 sedangkan nilai VIF variabel current ratio, debt to equity ratio, firm size dan working capital berada di bawah 10 . Dengan demikian uji multikolinearitas tidak terjadi regresi antar variabel independen.

\subsubsection{Uji Heteroskedastisitas}

Hasil pengujian heteroskedastisitas dengan menggunakan analisis grafik dapat dilihat dari grafik scatter plot sebagai berikut:

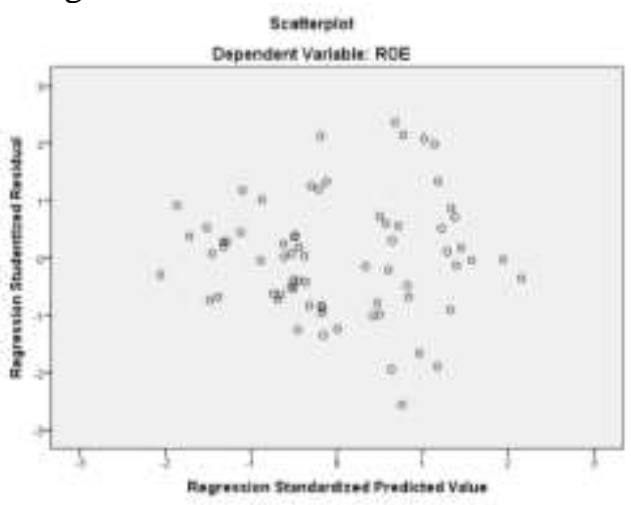

Gambar 3. Hasil Pengujian eteroskedastisitas

Sumber: Hasil Pengolahan, 2020

Berdasarkan grafik scatterplot terlihat bahwa titik-titik menyebar secara acak dan tersebar di posisi atas maupun di bawah angka nol pada sumbu $Y$. Kesimpulan yang dapat diambil adalah bahwa tidak terjadinya heteroskedastisitas pada model penelitian ini. Model penelitian ini disimpulkan layak untuk dipakai. 


\subsubsection{Uji Autokorelasi}

Hasil pengujian autokorelasi adalah sebagai berikut:

Tabel 5. Pengujian Autokorelasi

\begin{tabular}{ccc}
\hline $\mathrm{dW}$ & $\mathrm{dU}$ & Keputusan \\
\hline 1.974 & 1.702 & $\begin{array}{c}\text { tidak terjadi } \\
\text { autokorelasi positif } \\
\text { dan negatif }\end{array}$ \\
\hline
\end{tabular}

Sumber: Hasil Pengolahan, 2020

Berdasarkan tabel 4. di atas menunjukkan hasil pengolahan data diperoleh nilai statistik Durbin-Watson (DW) sebesar 1.974. Apabila dilihat dari tabel uji Durbin-Watson pada signifikan 0,05 untuk jumlah variabel independen sebanyak 4 dan jumlah sampel sebanyak 40 diperoleh batas bawah nilai tabel $(\mathrm{dL})=$ 1.284 dan batas atasnya $(\mathrm{dU})=1.720$. Karena nilai DW $=2.078$ yang diperoleh lebih besar dari du dan lebih kecil dari nilai $(4-\mathrm{du}=4-1.720=2.280)$ yaitu $1.284<1.974<2.280$ maka dapat disimpulkan hasil test uji autokorelasi tidak terjadi autokorelasi positif dan negatif.

\subsubsection{Uji Koefisien Determinasi}

Koefisien determinasi ( $\mathrm{R}$ square atau $\mathrm{R}^{2}$ ) bermakna sebagai sumbangan pengaruh yang diberikan variabel bebas (independent (variabel X)) terhadap variabel terikat (dependen (variabel Y)) atau dengan kata lain bahwa uji ini untuk menganalisis seberapa besar kontribusi pengaruh yang diberikan variabel terikat terhadap variabel bebas.

\section{Tabel 6. Koefisien Determinasi}

\begin{tabular}{|c|c|c|c|c|c|}
\hline \multicolumn{6}{|c|}{ Model Summary ${ }^{\mathrm{b}}$} \\
\hline $\begin{array}{c}\text { Mode } \\
1\end{array}$ & $\mathrm{R}$ & $\begin{array}{c}\mathrm{R} \\
\text { Squar } \\
\mathrm{e}\end{array}$ & $\begin{array}{l}\text { Adjuste } \\
\text { d R } \\
\text { Square }\end{array}$ & $\begin{array}{l}\text { Std. } \\
\text { Error of } \\
\text { the } \\
\text { Estimat } \\
\mathrm{e}\end{array}$ & $\begin{array}{c}\text { Durbin } \\
- \\
\text { Watso } \\
n\end{array}$ \\
\hline 1 & $\begin{array}{r}.794 \\
\mathrm{a}\end{array}$ & .631 & .589 & .77728 & 1.974 \\
\hline
\end{tabular}

Predictors: (Constant), Working_Capital, DER, CR, Firm_Size

b. Dependent Variable: ROE

Sumber : Hasil Pengolahan, 2020
Pada tabel 5 menunjukkan angka $\mathrm{R}^{2}$ atau $\mathrm{R}$ square sebesar 0.631 atau $63.1 \%$. Hal ini memiliki arti bahwa $63.1 \%$ pengaruh return on equity dapat dijelaskan oleh variasi dari keempat variabel independen yaitu current ratio, debt to equity ratio, firm size dan working capital. Sedangkan sisanya sebesar 36.9 $\%$ dijelaskan oleh variabel lain yang tidak diteliti pada penelitian ini. Variabel lain yang tidak diteliti pada penelitian ini dapat berupa karakter perusahaan secara operasional, manajemen perusahaan seperti CGC dan CSR, hingga beberapa rasio keuangan diluar dari penelitian ini.

\subsubsection{Uji Simultan (Uji F)}

Hasil Pengujian statistik simultan ditunjukkan pada tabel 5 di bawah ini :

Tabel 7. Uji Simultan (Uji F)

\begin{tabular}{cc}
\hline F & Sig. \\
\hline 14.951 & 0.00 \\
\hline
\end{tabular}

Sumber : Hasil Pengolahan, 2020

Hasil $\mathrm{F}$ hitung pada tabel 6 . di atas menunjukkan uji signifikansi simultan/bersama-sama (uji statistik F)

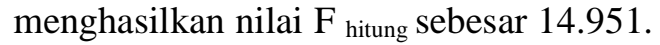
Pada derajat bebas $1(\mathrm{df} 1)=\mathrm{k}-1=4-1$ $=3$, dan derajat bebas $2(\mathrm{df} 2)=\mathrm{n}-\mathrm{k}=40-$ $4=36$, dimana $\mathrm{n}=$ jumlah sampel, $\mathrm{k}=$ jumlah variabel, nilai $\mathrm{F}$ tabel pada taraf kepercayaan signifikansi 0,05 adalah 0.00 dengan demikian $\mathrm{F}_{\text {hitung }}=14.951>\mathrm{F}_{\text {tabel }}$ $=2.87$ dengan tingkat signifikansi 0,000 . Karena probabilitasnya signifikansi jauh lebih kecil dari sig 0,00<0,05, maka Ha ditolak artinya secara bersama-sama variabel current ratio, debt to equity ratio, firm size dan working capital berpengaruh terhadap return on equity pada perusahaan transportasi yang terdaftar di Bursa Efek Indonesia tahun $2015-2018$.

\subsubsection{Uji Parsial (Uji t)}

Berdasarkan hasil uji statistik t tampak secara parsial pengaruh kedua variabel terhadap variabel dependennya seperti ditunjukkan pada tabel 6 sebagai berikut : 
Tabel 8. Uji Parsial (Uji t)

\begin{tabular}{cccc}
\hline Variabel & $\mathrm{B}$ & $\mathrm{t}$ & Sig.t \\
\hline Konstanta & -.828 & -.548 & .587 \\
CR & -.003 & -.028 & .978 \\
DER & .737 & 7.153 & .000 \\
Firm_Size & .013 & .231 & .818 \\
Working_Capital & 6.584 & .914 & .367 \\
\hline
\end{tabular}

Sumber: Hasil Pengolahan, 2020

Hasil uji secara parsial (uji-t) variabel current ratio menunjukkan nilai $\mathrm{t}_{\text {hitung }}<\mathrm{t}$ tabel $(-.028<2.021)$ dan nilai signifikansi di atas $0.05(.978>0.05)$ yang berarti tidak terdapat pengaruh signifikan antara variabel current ratio terhadap return on equity pada perusahaan transportasi yang terdaftar di Bursa Efek Indonesia tahun 2015 - 2018. Hasil penelitian ini tidak mendukung penelitian yang dilakukan oleh Hantono yang menyatakan bahwa current ratio berpengaruh signifikan terhadap return on equity (Hantono, 2015). Namun hasil penelitian ini sejalan dengan Zaman yang menyatakan bahwa current ratio tidak berpengaruh signifikan terhadap return on equity (Zaman et al., 2017). Berdasarkan hasil tersebut manajer perusahaan perlu menjaga tingkat likuiditas perusahaan karena apabila tingkat likuiditas baik, maka perusahaan dalam menghasilkan laba perusahaan juga akan meningkat.

Hasil uji secara parsial (uji-t) variabel debt to equity ratio menunjukkan nilai $\mathrm{t}$ hitung $<\mathrm{t}$ tabel $(7.153>2.021)$ dan nilai signifikansi di bawah $0.05(.0 .00<0.05)$ yang berarti terdapat pengaruh signifikan antara variabel debt to equity ratio terhadap return on equity pada perusahaan transportasi yang terdaftar di Bursa Efek Indonesia tahun 2015 - 2018. Hasil penelitian ini mendukung penelitian yang dilakukan oleh Hantono menyatakan bahwa debt to equity ratio berpengaruh signifikan terhadap return on equity (Hantono, 2015) dan Violita yang menyatakan bahwa debt to equity ratio meningkat maka return on equity akan meningkat, begitu juga sebaliknya apabila nilai debt to equity ratio menurun maka return on equity juga akan menurun (Violita dan Sulasmiyati, 2017). Namun hasil penelitian ini tidak sejalan dengan penelitian yang dilakukan oleh Isbanah yang menyatakan bahwa perusahaan akan menjadi kurang baik apabila menggunakan utang semakin besar (Isbanah, 2015). Kondisi ini mengakibatkan sumber dana yang lebih besar maka keuntungan dapat meningkat yang diikuti pula dengan peningkatan resiko yang lebih besar dari peningkatan keuntungan sehingga hasil penelitian ini juga menunjukkan bahwa leverage tidak berpengaruh terhadap return on equity.

Hasil uji secara parsial (uji-t) variabel firm size menunjukkan nilai $\mathrm{t}_{\text {hitung }}<\mathrm{t}_{\text {tabel }}$ $(.231<2.021)$ dan nilai signifikansi di atas $.818(.818>0.05)$ yang berarti tidak terdapat pengaruh signifikan antara variabel firm size terhadap return on equity pada perusahaan transportasi yang terdaftar di Bursa Efek Indonesia tahun 2015 - 2018. Hasil penelitian ini sejalan dengan Talebnia yang menjelaskan bahwa tidak terdapat pengaruh ukuran perusahaan terhadap kinerja perusahaan (Talebnia et al., 2010). Namun penelitian ini tidak sejalan dengan penelitian yang dilakukan oleh Wibowo yang menyatakan bahwa firm size berpengaruh terhadap kinerja keuangan (Wibowo, 2019). Dalam hal ini menunjukkan bahwa ukuran perusahaan tidak bisa memberikan jaminan bahwa perusahaan akan memiliki return on equity yang baik.

Hasil uji secara parsial (uji-t) variabel working capital menunjukkan nilai $\mathrm{t}$ hitung $<\mathrm{t}_{\text {tabel }}(.914<2.021)$ dan nilai signifikansi di atas $0.05(.367>0.05)$ yang berarti tidak terdapat pengaruh signifikan antara variabel working capital terhadap return on equity pada perusahaan transportasi yang terdaftar di Bursa Efek Indonesia tahun 2015 - 2018. Hal ini disebabkan karena semakin lamanya berputar modal kerja menyebabkan perolehan penjualan yang akan sangat berdampak pada potensi 
penurunan laba perusahaan tersebut dan sebaliknya. Hasil penelitian ini tidak mendukung penelitian yang dilakukan oleh Bulan yang menyatakan bahwa modal kerja berpengaruh signifikan terhadap profitabilitas (Bulan, 2015).

\section{KESIMPULAN DAN SARAN \\ 5.1 Kesimpulan}

Penelitian ini menguji bagaimana pengaruh current ratio, debt to equity ratio, firm size dan working capital berpengaruh terhadap return on equity pada perusahaan transportasi yang terdaftar di Bursa Efek Indonesia tahun 2015 - 2018. Berdasarkan hasil penelitian ini dapat disimpulkan bahwa:

1. Current ratio secara parsial tidak berpengaruh terhadap return on equity pada Perusahaan Transportasi yang Terdaftar di Bursa Efek Indonesia Tahun 2015 - 2018.

2. Debt to equity ratio secara parsial berpengaruh terhadap return on equity pada Perusahaan Transportasi yang Terdaftar di Bursa Efek Indonesia Tahun 2015 - 2018.

3. Firm size secara parsial tidak berpengaruh terhadap return on equity pada Perusahaan Transportasi yang Terdaftar di Bursa Efek Indonesia Tahun 2015 - 2018.

4. Working capital secara parsial tidak berpengaruh terhadap return on equity pada Perusahaan Transportasi yang Terdaftar di Bursa Efek Indonesia Tahun 2015 - 2018.

\subsection{Saran}

Penelitian yang dilakukan ini dapat memberikan beberapa saran-saran sebagai berikut :

1. Bagi para peneliti berikutnya, dapat menggunakan variabel bebas lainnya selain variabel yang digunakan dalam penelitian ini sehingga dapat memberikan informasi yang lebih luas mengenai pengaruh terhadap profitabilitas. Peneliti berikutnya disarankan untuk menambah periode penelitian serta menggunakan pembatasan lain agar penelitian selanjutnya yang dihasilkan lebih tepat dan akurat.

2. Bagi para investor diharapkan dapat menggunakan informasi dari hasil penelitian untuk sebagai bahan analisis dalam proses pengambilan keputusan investasi. Ketersediaan informasi hasil penelitian dapat memberikan masukan yang mempermudah untuk melihat potensi kenaikan keuntungan perusahaan sehingga dapat meningkatkan hasil investasi.

\section{DAFTAR PUSTAKA}

Alpi, M. F. (2018). Pengaruh Debt To Equity Ratio, Inventory Turn Over, Dan Current Ratio Terhadap Return On Equity Pada Perusahaan Sektor Farmasi Yang Terdaftar Di Bursa Efek Indonesia. http://hdl.handle.net/11617/9910

Bulan, T. P. L. (2015). Pengaruh Modal Kerja terhadap Tingkat Profitabilitas pada PT Adira Dinamika Multi Finance Tbk. Jurnal Manajemen Dan Keuangan, 4(1). https://www.ejurnalunsam.id/index. php/jmk/article/view/277

Hantono. (2018). Konsep Analisa Laporan Keuangan dengan Pendekatan Rasio dan SPSS. Deepublish.

https://books.google.co.id/books?id $=$ AiRtDwAAQBAJ

Hantono, H. (2015). Pengaruh Current Ratio dan Debt To Equity Ratio Terhadap Profitabilitas pada Perusahaan Manufaktur Sektor Logam dan Sejenisnya yang Terdaftar di Bursa Efek Indonesia Periode 2009-2013. Jurnal Wira Ekonomi Mikroskil: JWEM, 5(1), 21-30.

https://mikroskil.ac.id/ejurnal/index .php/jwem/article/view/222/145

Isbanah, Y. (2015). PENGARUH ESOP, LEVERAGE, AND UKURAN 


\section{PERUSAHAAN}

KINERJA

TERHADAP

KEUANGAN

PERUSAHAAN DI BURSA EFEK

INDONESIA. Jurnal Riset Ekonomi

Dan Manajemen, 15(1), 28. https://doi.org/10.17970/jrem.15.15 0103.ID

Jannati, I. D. (2014). PENGARUH RASIO LEVERAGE TERHADAP PROFITABILITAS (Studi Pada Perusahaan Makanan Dan Minuman Yang Terdaftar din BEI Periode Tahun 2009-2011). Jurnal Administrasi Bisnis, 8(2). http://repository.ub.ac.id/id/eprint/1 16150

Kasmir. (2013). Analisis Laporan Keuangan (5th ed.). PT. Raja Grafindo Persada.

Makhdalena, M. (2018). PENGARUH BLOCKHOLDERS OWNERSHIP, FIRM SIZE DAN LEVERAGE TERHADAP KINERJA KEUANGAN PERUSAHAAN. EKUITAS (Jurnal Ekonomi Dan Keuangan), 18(3), 277-292. https://doi.org/http://dx.doi.org/10.2 4034/j25485024.y2014.v18.i3.136

Mareta, A. Dela. (2013). PENGARUH FINANCIAL LEVERAGE TERHADAP PROFITABILITAS (Studi pada Perusahaan Sektor Makanan dan Minuman yang Terdaftar Di Bursa Efek Indonesia Periode 2009-2011). Jurnal Administrasi Bisnis, 1(2), 132-139. http://administrasibisnis.studentjour nal.ub.ac.id/index.php/jab/article/vi ew/49/1600

Rudianto. (2013). Akuntansi Manajemen : Informasi untuk Pengambilan Keputusan Strategis (viii). Erlangga.

Sartono, R. A. (2012). Manajemen Keuangan Teori dan Aplikasi (4th ed.). BPFE.

Sugiyono, M. (2015). penelitian \& pengembangan (Research and Development/R\&D). Bandung: Penerbit Alfabeta.

Sunyoto, D. (2013). Dasar-dasar
Manajemen Keuangan Perusahaan. Caps Publishing.

Talebnia, G., Salehi, M., Valipour, H., \& Shafiee, S. (2010). Empirical Study of the Relationship between Ownership Structure and Firm Performance: Some Evidence of Listed Companies in Tehran Stock Exchange. Journal of Sustainable Development, $3(2), \quad 264$. https://doi.org/10.5539/jsd.v3n2p26 4

Tnius, N. (2018). PENGARUH MODAL KERJA TERHADAP PROFITABILITAS PADA PT. HANJAYA MANDALA SAMPOERNA TBK. Jurnal SEKURITAS (Saham, Ekonomi, Keuangan Dan Investasi), 1(4). https://doi.org/10.32493/skt.v1i4.13 80

Violita, R. Y., \& Sulasmiyati, S. (2017). Pengaruh Struktur Modal Terhadap Profitabilitas (Studi Pada Perusahaan Food and Baverages Yang Terdaftar di BEI Tahun 20132016). Jurnal Administrasi Bisnis, $51(1)$, 138-144. http://repository.ub.ac.id/id/eprint/3 445

Wardojo, C. A. I., Anggraeni, L., \& Sasongko, H. (2004). PENGARUH LIKUIDITAS MODAL KERJA TERHADAP PROFITABILITAS PERUSAHAAN SEKTOR PERUNGGASAN YANG TERDAFTAR DI BURSA EFEK INDONESIA. Jurnal Manajemen Dan Agribisnis, 13(3), 206. https://doi.org/10.17358/jma.13.3.2 06

Wibowo, N. (2019). PENGARUH FIRM SIZE DAN LEVERAGE RATIO TERHADAP KINERJA KEUANGAN PADA PERUSAHAAN

PERTAMBANGAN. Jurnal Wira Ekonomi Mikroskil: JWEM, 9(1), 13-20.

https://mikroskil.ac.id/ejurnal/index 
.php/jwem/article/view/588/283

Zaman, B., Ak, M., Solikah, M., \& Ak, M. (2017). JURNAL PENGARUH DEBT TO EQUITY RATIO , CURRENT RATIO , NET PROFIT MARGIN , DAN TOTAL ASSET TURN OVER TERHADAP RETURN ON EQUITY EFFECT OF DEBT TO EQUITY RATIO , CURRENT RATIO, NET PROFIT MARGIN , AND TOTAL ASSET TURN OVER ON RETURN ON EQUITY Oleh : Ni' m. SimkiEconomic Vol. 01 No. 10 Tahun 2017 ISSN : BBBB-BBBB, O1(10). http://simki.unpkediri.ac.id/mahasis wa/file_artikel/2017/cd72c8becae8e a9f7baee2f2e0f60418.pdf 